Submission of manuscripts Papers may be submitted to any member of the editorial board. Three copies should be sent; originals of figures should not be included until the paper has been accepted. Upon acceptance of a paper, the author will be asked to transfer copyright to the publisher. Papers may be submitted electronically by sending a LaTeX file to EJAM@VAX.OX.AC.UK; this file should include the figures (line figures only). Electronic communications can also be used for minor corrections and for messages to the editors.

Layout of manuscripts Papers should be typewritten in double spacing throughout, on one side of the paper. Please avoid footnotes if possible. Papers must begin with an abstract of not more than 300 words, and they should end with a brief concluding section. The SI system of units must be used throughout. There is no formal restriction on length, but the constraint of fitting an integral number of papers into 96 pages means that short papers (20 typed pages or fewer) are likely to appear sooner than the long ones.

Illustrations Figures should be drawn in indian ink on good quality white paper or produced by computer to comparable quality. Wherever possible they will be reproduced with the author's lettering. A list of captions for figures should be attached separately.

Where appropriate, articles may be illustrated by photographs: high-quality glossy black and white prints are necessary.

References References should be listed in alphabetical order at the end of the main text. Please include the article title in the reference, which should be in the order: author's surname, initials; year in parentheses; article title; journal name, abbreviated in accordance with the World List of Scientific Periodicals (4th Edn); volume number (underlined); inclusive page numbers.

Citations in the text Any unambiguous system is acceptable. Three recommended ways of citing a 1992 paper by A. European are: European (1992); European [Eu]; European [7]. In the second case, the reference at the end of the text should be preceded by [Eu], and in the third by [7]. Please note that in the third system, alterations may lead to wholesale renumbering.

\title{
EDITORIAL POLICY
}

The European Journal of Applied Mathematics aims to publish papers in all areas of applied mathematics, with especial emphasis on the following.

(i) The exposition of new mathematical ideas relevant to the modelling and analysis of modern technological processes.

(ii) The development of interesting mathematical methods with broad areas of applicability.

There is no restriction in the areas of applicability or the style of mathematics as long as the content is presented so as to be as accessible as possible to the entire community of mathematicians and mathematical scientists. This applies in particular to the introductory section of the paper. Standard mathematical techniques will only be published if they are associated with novel applications or lead to substantial advances in established problem areas.

\section{COPYING}

This journal is registered with the Copyright Clearance Center, 222 Rosewood Drive, Danvers, MA 01923. Organisations in the USA who are also registered with the C.C.C. may therefore copy material (beyond the limits permitted by sections 107 and 108 of US copyright law) subject to payment to C.C.C. of the per-copy fee of $\$ 11.00$. This consent does not extend to multiple copying for promotional or commercial purposes. Code 0956$7925 / 95 \$ 11.00+.10$.

Organisations authorised by the Copyright Licensing Agency may also copy material subject to the usual conditions.

ISI Tear Sheet Service, 3501 Market Street, Philadelphia, Pennsylvania 19104, USA, is authorised to supply single copies of separate articles for private use only.

For all other use, permission should be sought from the Cambridge or the American Branch of Cambridge University Press.

(c) Cambridge University Press 1995

CAMBRIDGE UNIVERSITY PRESS

The Pitt Building, Trumpington Street, Cambridge CB2 IRP

40 West 20th Street, New York, NY 10011-4211, USA

10 Stamford Road, Oakleigh, Melbourne 3166, Australia 
European Journal of

Applied Mathematics

VOLUME 6·PART 6 · DECEMBER 1995

\section{CONTENTS}

Asymptotics of slow flow of very small exponent power-law shear-thinning fluids

M. E. BREWSTER, S. J. CHAPMAN, A. D. FITT and C. P. PLEASE

Diffractive optics in nonlinear media with periodic structure

G. BAO and D. C. DOBSON

On boundary value problems in fracture of elastic composites

G. S. MISHURIS and Z. S. OLESIAK

Functional series and Hashin-Shtrikman type bounds on the effective conductivity of random media

K. Z. MARKOV and KR. D. ZVYATKOV

A differential constraints approach to partial invariance

J. ONDICH

On long-wave morphological instabilities in directional solidification

A. C. SKeldon, G. B. MCFADDEN, M. D. IMPEY, D. S. RILEY, K. A. CLIFFe,

A. A. WHEELER and S. H. DAVIS

Author index to Volume 6 